\title{
THE UNITED NATIONS ISTANBUL SEMINAR ON THE INTERNATIONAL RESPONSIBILITY FOR THE INDEPENDENCE OF NAMIBIA
}

\author{
by \\ Dr. TƯRKKAYA ATAOUV \\ Chairman of the \\ International Relations \\ Division, Ankara University; \\ Executive Council member, \\ International Organization \\ for the Elimination of All \\ Forms of Racial Discrimina- \\ tion (U.N.).
}

The U.N. Seminar on the International Responsibility for the Independence of Namibia was held in Istanbul (Turkey) from 21 to 25 March 1988, starting on the day of the 28th anniversary of the Sharpeville tragedy. The Seminar was held under Resolution $42 / 14 \mathrm{C}$ and $\mathrm{D}$, in which the General Assembly decided in 1987 that the United Nations Council fcr Namibia should organize international and regional activities with a view to intensifying active support for the Namibian cause. The purpose of the Seminar would be to obtain up-to-date information on the situation in that Territory and to consider means of mobilizing more concerted and effective action in support of its immediate independence. The Seminar was expected to touch upon all the aspects of the question, especially taking into account how the situation had changed since 1966, when the U.N. General Assembly ended South Africa's Mandate over Namibia.

The Seminar was hosted by the Government of Turkey, a founding member of the U.N. Council for Namibia. As Professor Ali Bozer, the Minister of State and the Acting Foreign Minister, said in his Opening Statement, Turkey has always been closely associated with the developments concerning Namibia. The Turkish Minister considered this Seminar as "a renewed expression" of the support that Turkey was giving to the Namibian cause. The Turkish Ambassadors Inal Batu and Yüksel Söylemez have reminded the audience that Turkey was the only Western co-sponsor of the historic Resolution 2145 in 1966, which terminated the 
Mandate for South Africa and brought the territory under international responsibility. The latter Turkish diplomat was present there and played a part, at the Twenty-First Session of the General Assembly, in this historic perspective which turned out to be a true landmark. It was also reminded that the U.N. Fund for Namibia and the U.N. Institute for Namibia both had Turkey's full support, that Turkey. was continuing to contribute to different funds of the U.N. and that Turkey had given scholarships to Namibian students who were studying in that country.

When the United Nations was founded in 1945, one of the principles to which members pledged themselves was set forth in Chapter XI of the Charter, containing the Declaration regarding Non-Self-Governing Territories $(8,9) .^{*}$ Article 73 in that Chapter stated that the U.N. members which assume responsibilities for the territories whose peoples have not yet attained self-government recognize the principle that the interests of the inhabitants of these territories are paramount and that they accept as a sacred trust the obligation to promote to the utmost the well-being of the inhabitants of these territories. Chapter XI applied to all non-self-governing territories. It is also well-known that under Chapter XII, the U.N. established under its authority an international trusteeship system. which applied as well to territories held as League of Nations Mandates.

The General Assembly recommended that South West Africa be placed under the Trusteeship System and invited the then Union of South Africa to propose a trusteeship agreement for the territory. In 1949, South Africa, now under National Party rule, informed the U.N. that it would no longer transmit information on its administration of the territory on the grounds that the Mandate had lapsed with the demise of the League. The International Court of Justice, in an advisory opinion in 1950, found that South West Africa was still a territory under international Mandate and South Africa continued to have the obligation to submit reports on it. The Court further declared that the supervisory functions of the League were to be exercised by the U.N. South Africa continued to oppose any form of U.N. supervision.

For the next fifteen years, the General Assembly sought to reach agreement with South Africa on the implementation of the advisory opinion, but without success. In the meantime, the South African Government took over directly the administration of native affairs and began to implement the policy of apartheid. The General Assembly was lefi with no choice but to decide on October 27, 1966, that South Africa's

* For references, see page 27. 
Mandate was terminated and that henceforth the Territory would be under the direct responsibility of the U.N. Turkey was a founding member of the U.N. Council for South West Africa (now Namibia), established in 1967 as the legal authority to administer the Territory until independence, and in the meantime, to prepare it for independence. Turkey has been an active member ever since.

The Seminar was attended by the representatives of NGOs, national support groups and liberation movements as well as by parliamentarians, scholars, trade unionists and media representatives. Several representatives of member states and U.N. bodies were also present as observers.

The participants discussed the historical background, the Namibian economy and the strategies to promote the independence of Namibia. Against this background, they considered recent developments affecting the struggle of the Namibians for self-determination and independence. They noted the strong growth of the labour movement and the intensified popular resistance against the South African occupation régime. They discussed the impact of the continuing collaboration of some governments with South Africa. They considered the efforts to secure implementation of the U.N. plan for independence, with particular attention to the initiative undertaken recently by the U.N. Secretary General.

Several representatives made important opening statements, all bringing the issue up-to-date. For instance, Sylvester Jarrett from Liberia, who was also the Chairman of the Council for Namibia Seminar, concluded that comprehensive and mandatory sanctions were the only means of achieving South African withdrawal. It was unfortunately precisely those governments which wielded the most influence on the Pretoria régime and whose adoption of sanctions would really make a difference, which had refused to take the necessary measures. He also emphasized that international assistance to SWAPO was essential for hastening South Africa's withdrawal.

Ammar Amari from Tunisia, speaking on behalf of the Special Committee of Decolonization and the Committee on the Exercise of the Inalienable Rights of the Palestinian People, said that the Pretoria rógime intended to keep its troops in Namibia and use them to carry out aggression against the neighbours. Using the support of its allies, South Africa was managing to lead negotiations to a dead end by introducing extraneous issues to Namibian independence. He regretted that the' Security Council was unable to apply even minimum and selective sanctions due to the negative votes of two permanent members.

Ahmat Farouk Arnous from Syria, speaking for the Special Com- 
mittee Against Apartheid, scored that Pretoria's increased repression and violence as well as continued plundering of Namibia's natural resources were matters of grave conzern. The only peaceful means left of the resolution of the crisis was the imposition of comprehensive mandatory sanctions against the apartheid régime. The call for such action had to be heeded urgently.

Mr. Bernt Carlsson, the U.N. Commissioner for Namibia, reminded that the United Nations had been seized of this problem for more than forty years. The fact that this Namibian question remained unsolved had resulted in the continued :epression and exploitation of the people. Furthermore, it presented a challenge to the authority of the U.N. The continued illegal occupation of Namibia had also affected adversely the peace, security and development of the southern Africa region as a whole. Mr. Carlsson added that $198 \%$ was the tenth year of the adoption of the U.N. plan for the independenze of Namibia, endorsed by Security Council Resolution 435 (1978).

Karl Kapelwa, the representative of SWAPO, said that now it was the time for action. He gave examples of the unparallelled abuse of human dignity by the illegal occupettion régime in Namibia. The latest in the chain of South Africa's act of barbarity came on February 19, 1988, when a bomb went off at the town of Oshakati in northern Namibia in an over-crowded bank. 27 peop.e died. There was circumstancial evidence proving South African intelligence's involvement in the bombing.

The speakers who dwellıd on the historical background reminded the audience on some highlights of the colonization period, the Mandate and its revocation as well as the current role of the international community. It was pointed out that, in keeping with racist arrogance, colonial natives were declared non-existent. The European "discoverers" named the countries and the natives. While settlers from the Cape Colony first referred to Namibia as "Trarısgarieb", then simply "South West Africa", to be changed to "German South West Africa" $(4,7)$.

Much of the existing literature on Namibia is from the pens of apologists of the colonial sy:stem of imperialısm, i.e., colonial officials, pro-imperialist missionaries and other European fortune seekers. Colonialism has always sought to legitimize its authority by confronting its subjects with a caricature of their historical identity. The South African occupiers propagate a set of myth about pre-colonial society in Namibia. Stating that there were endjess inter-tribal warfare, they suggest that only under colonial hegemon! is 'progress' conceivable. 
But the colonial myth is an inverted image of reality. Before colonisation, the Namibian people had evolved a veriety of forms of substance. The Khoisan communities along the coastal Namib Desert lived on the produce of the sea; the Nama in the southern interior herded sheep and goat; the Herero raised cattle; the Damara cultivated small plants and the San hunted across the waterless plains of the Kalahari. The people moved freely from one area to another. There was a network of long-distance trade. Much earlier than the foreign companies, Owambo and San smiths mined copper at Otavi, iron ore at Kassinga and salt from the Etosha Pan.

South West Africa was colonized by the Germans (2) when the leading European nations were attending the Berlin Conference (1884-85). to partition among themselves. Initial expansion had taken place on the initiative of Germany's banking merchant capitalists, who were interested mainly in quasi-monopolistic land concessions. It was the discovery of diamonds in Western Griqualand in 1870 which gave the impetus to land speculations by Adolf Luderitz, the first German banking merchant to acquire extensive land ownership in Namibia. The area over which he acquired land ownership was geologically related and adjacent to Western Griqualand. He had seen potential for diamonds, copper and gold mining in the region.

It was Luderitz's acquisition of that extensive land ownership which served as Bismarck's declaration of South West Africa as a German Protectorate in 1884. The German flag followed German merchandise; it was the economic interest which formed the primary motive behind that expansion. Bismarck had then dispatched there a certain Dr. Göring as Imperial Commissioner. His son, Hermann Göring, was later to add even more infamy to that name. It was at that time that this land was passing through a process of important social change. The tribal communities were breaking up, giving way to the larger, feudal states. The struggle for territorial supremacy between the Herero and the Nama chiefs were not in terms of internecine tribal warfare, but in terms of the conditions of a feudal state in the making. That is, before the end of the century, the Herero and the Nama forefathers of the Namibians had still not grasped the fact that the fundamental contradiction was not between the two native communities, but between the natives as a whole on the one hand and the German imperialists on the other. This historic mistake of the forefathers, which spelled disaster to the Namibian people, should be a useful lesson to the Namibian liberation fighters today.

It was in the light of this realization that the Hereros and the 
Namas finally signed a peace agreement in 1892. They were now turning their swords jointly against the foreign plunderers. The war of resistance took the German governor by surprise. His first reaction was to attempt to negotiate with the Herero King. But the German Government got directly involved, dispatching reinforcements. The determined resistance of the natives made the Germans even more adamant in teaching the Africans a "lesson". General Lothar von Trotha, the former commander of the German forces in Africa, was appointed to head the reinforcements. Von Trotha had participated in the suppression of the Boxer revolt and that of the Wahehe uprising in Tanganyika. The Hereros were engaged $n$ a decisive battle at Waterberg in 1904. They were overwhelmed by superior German might. Throwing a cordon across the land to seal off all escape routes, the German general issued his notorious extermination crder. He carried out the campaign against the Hereros and the Namas with appalling cruelty. The Germans conducted a war of genocide. The Herero were reduced from cattle-rich tribesmen to 15,000 starving fugitives. More than half of the Nama and the Berg-Damara had died.

In 1905 , Germany began drafting its native regulations. Emperor Wilhelm the Second signed the formal order of expropriation of tribal lands. All Africans over the age of eight had to carry an identity card or pass. Any European had the right to arrest an African. And the labour contracts completed tive system of control. The land and cattle of the natives were systematisally and unscrupulously expropriated. The economic life of the tribal communities was in total ruin.

The former pattern had been shattered by the intrusion of external forces. An aggressively expanding colonialism at the Cape had previously begun to push waves of migration. Missionaries began to penetrate. Hard on their heals had come the traders. Drawn by the lure of quick profits, they had penetrated into the country from their supply bases at Walvis Bay and elsewhere. Greedy for slaves, cattle and ivory, they had given the people liquor and guns. The Namibian rulers fell into debt. For decades, the colonial circles fought bitterly over the spoils like a pack of wolves.

The sudden eagerness of imperialist capital to plunder Namibia's resources created a massive demand for labour. No sooner had German military barbarism reduced the black population than mining began to boom. Motivated by a desperate need for wage-labourers, the régime imposed a labour code, which made the African only a working unit. They were forbidden to acquire land or any large stock of animals. They were compelled by law to labour at whatever job their colonial masters 
allotted to them. Natives who were under a contract to work or who were employed as servants could be sentenced to corporal punishment. or imprisonment in irons. No judicial trial was required, but the application of the master.

It was only when official records were examined and the African victims were encouraged to testify following the successful South African invasion in 1915 that a glimpse of German brutality was gained. Britain had called on General Louis Botha, South Africa's first Prime Minister, to invade the German colony of South West Africa. South: African troops invaded the land under the command of Generals Jan C. Smuts and Botha. It is significant that General Botha had then rejected the offer of help from the native Rehoboth leaders, stating that this was a "white man's war". German brutal treatment was displayed with the publication of the British Blue Book in 1918, not because the newcomers wanted to champion the African cause, but to discredit the German one.

Hence, as soon as South Africa took charge, it discharged emissaries to announce its occupation. Smuts and Botha, in fact, saw an identity of interests with the German settlers. Hence, although the Versailles Treaty of 1919 gave the mandatories the right to repatriate the enemy nationals and confiscate their property, the South Africans allowed the German farming and trading community to remain.

Asserting that the natives could not govern themselves, the South: Africans tried to annex the land. When the Mandate was finally transferred to the Government of the Union of South Africa, this was nothing but annexation. The Mandate system as a whole was a thin veil for the division of spoils. South Africa basically followed German repressive colonial policies. For example, Germany had created the Police Zone in 1911; the Union carried over this law through Proclamation No. 15 of 1919. Germany had left African education to the missionaries. South Africa continued the same until 1935 (when it established one government school for Africans). South Africa continued the German practice of prohibiting the Africans 1 to own land. Germans required all African males over fourteen to do the same. The Germans distributed Africans among farms, rnines and railroads. wherever labour was needed; South Africa continued this practice. The Germans and the South Africans both made arbitrary arrests, tortured and killed. Other practices were the parcelling out of African prisoners between public and private employers, arrest of Africans for "Iaziness", "insulance" or "vagrancy" and the giving to white employers the right to arrest Africans. (4) 
Helmut P. Angula, SWAPO Permanent Observer to the U.N., stated that the Istanbul Seminar was meeting at a crucial time in the history of the liberation struggle of South Africa and Namibia. He added that the embattled Namibian people, under the leadership of SWAPO, were watching these deliberations with keen interest.

One may pose here and remind the reader of the historical development of SWAPO. The fundamental question which confronted the Namibian people during the latter half of the 1950 s was the establishment of a political organization capable of providing leadership. SWAPO was thus formed on April 19, 1960 , as a concrete response to that fundamental need. The initial reaction of the racist régime to the formation of SWAPO was to nip the young movement in the bud by restricting most of its leading activists as well as by forcing many of its leaders into exile. These measures of repression taught the Namibian people that only a political organization with firm roots in the broad masses could bring the liberation struggle to a successful conclusion. To this end, steps were taken to establish branches in different parts of the country, especially in the industrial areas of Windhoek; Otjiwarongo, Tsumeb, Walvis Bay, Luderitz Bay and Oranjemund.

Since the system of contract labour is one of the most blatant manifestations of colonial exploitation, it was essential to try to root the movement in the workers' section of the population. This task entailed the concentration of the principal issues around which the masses had to be mobilised. But since this trend represented a direct antithesis to South African colonialism, it brought about new waves of repression against SWAPO. For instance, by the end of 1963, the South African Government banned all public meetings in Namibia. Some SWAPO leaders and members came under severe harassments in the form of dismissals from jobs and expulsions from urban centers to the countryside. The government also set up the Odendaal Commission to draw up a plan for the balkanization of Namibia into Bantustans.

In the face of such new repression measures, it became necessary to establish the People's Liberation Army of Namibia (PLAN). The organizational structure of the party was also broadened by creating new departments, e.g. labour, women, youth and the like. The immediate effect of this program was manifested in the growing militancy of the Namibian populace as demonstrated by the historic 1971-72 general strike of workers. The change of government in Portugal in 1974 also brought a new dimension to the Namibian liberation struggle.

This writer stated in the Istanbul Seminar that SWAPO was the or- 
ganizational expression and embodiment of the Namibian people; it articulated their suffering and their longing for security and prosperity; it was their means of attaining justice; it was their shield and weapon against exploitation and oppression; it was a people's movement; it was the Namibian people organized. Misappreciation of this fact is the dilemma of the racists. Some circles want to see SWAPO as if it was a group of a few individuals against whom particular attitudes may be adopted. Denial of a SWAPO government leads to a dead end. There is no other workable alternative. We have witnessed the performances of Dick Mudge's Democratic Turnhalle Alliance (DTA), or Peter Kalangual's Christian Democratic Action (CDA). Some of them even admitted that they were striving to "win the country from SWAPO". The fact that a SWAPO Government has no alternative should behoove South Africa and its allies to come to terms with it. Stubborn refusal will lead to a tragic prolongation - that is all! That Namibia will be free, just like Zimbabwe, Angola and Mozambique, is inexorable. To prolongate the inevitable is tragic, because it is pointless. South Africa is confronted with a lesson without learning from it! Parliamentary maneouvres like the Turnhalle Conference are total farces. The whites are caught in their racism. Just as there is no alternative to Namibian independence, there is no alternative to a SWAPO Government; the two are organically linked. All else is doomed to failure (4).

The Seminar considered the structural distortions of the Namibian economy and the exploitation of its resources by foreign economic interests. As this writer briefly stated during the debates, colonized Namibia's economy is characterized by two prominent features:(a) the extensive foreign extraction of the country's varied natural resources, and (b) a subsistence agriculture enveloping the majority of the African population, forced to live in the Bantustans. This is the central dynamics of economic exploitation under the South African occupation. As the colonial power, the South African régime has structured the economy of the country according to the interests which it serves: in the first place, South African based capital and foreign based capital. The loca] settlers are subordinated to these interests as junior partners in exploitation. The South Africans have also subordinated the surviving pockets of the peasant economy of the Namibian people, already partially destroyed by their German predecessors, to their central design: namely, the building of a system of exploitation based on cheap wage labour. The peasant impoverishment forces them to work for very low wages, and the rural reserve army of labour is used, together with totalitarian 
labour controls, to keep the wages at starvation levels. For the foreigners this system guarantees exorbitant profits, and for the colonial régime it is a source of revenue and a corrective to South Africa's trade deficit $(1,3,4,5,6)$.

Hage Geingob, the Director of the U.N. Institute for Namibia, discussed the extensive foreign economic interests with special reference to transnational corporations (TNCs). Three export sectors, that is, mining, fishing and farming, account for nearly all commercial primary production in Namibia. That country is rich in mineral resources in demand throughout the industrial economies of the Western world. The coastal sands of the Southern Namib cover extensive fields of diamonds. On the central plateau, a large variety of base mineral ore bodies are located, notably copper, lead, zinc and coal. Inland, the Namib holds vast reserves of low-grade uranium. Prospecting has shown that the Walvis Ridge is potentially rich in supplies of oil and natural gas. Namibia is well endowed with mineral resources, some of which have not yet been properly prospected, much less put into production.

The pattern of mining (10) has been dominated by a very few large isolated operations. Between them Rossing Uranium Limited (R.U.L), Consolidated Diamond Mines (C.D.M.) and Tsumeb Corporation Limited (T.C.L:) control about $95 \%$ of mineral production and exports. Despite its diversity, virtually none of the industry is locally! owned, even partially, with the exception of a handful of small mines and the salt works north of Swakopmund. All major assets, and many of the smaller ones, too, are controlled by transnational corporations. Some 17 companies, all foreign-based, hold major and usually complete ownership in the significant mines on Namibian soil.

Apart from containing rich salt fields, the coast perhaps has the best fishing waters in the world (6). Before 1945, fishing consisted mainly of a small rock lobster industry and seal culling. Both of these resources have long been exploited to near their full potential. Now, the main activity is pelagic fishing. The cold Benguela Current produces the climate which renders the Namib a desert wasteland, but it also makes for one of the world's richest fishing grounds. All production is concentrated at the country's two ports in a small number of large and mechanized factories owned by interlocking companies.

Commercial farming in. Namibia has been from the start the creation of the colonial state. The Germans had, with isolated exceptions, expropriated from the native inhabitants, the plateaus of Central and Southern Namibia, which is the only viable farming country outside the 
north. The incoming South African administration encouraged the bulk of the German farmers to stay and divided up huge tracts of grazing land among the new settlers. The régime granted easy credit to them to purchase land and equipment, provided expert advice, offered technical services and gave access to the subsidized South African agricultural marketing system. By these means, thousands of white settlers were planted on the best agricultural land and raised to the mechanized commercial prosperity of the post-war years. The rise of commercial settler farming has been built almost exclusively on stock farming. Cattle and karakul pelts make up four-fifths of the farm sector's output.

With a population of 1.6 million, Namibia has one of the highest per capita incomes in Africa. It also has one of the world's most skewed income distribution patterns. Its economy is foreign trade oriented. It provides a lucrative, captive market to South Africa. The most pronounced attempt to preserve Namibia's natural resources came in 1974 when the U.N. Council for Namibia enacted Decree No. 1 for the Protection of the Natural Resources of Namibia against further usurpation by the apartheid régime and its allies.

Stating that foreign economic interests have been playing an important role in the Namibian conflict, Alfred Babing, from the Institute for International Politics and Economics of the German Democratic Republic, said that it was the political duty of those who stand in solidarity with the suppressed majority of the South African and Namibian populations to apply pressure to assist in a break-through of a policy in which the non-violent means of sanctions would help put an end to a violent régime. He also added that foreign economic interests could play a constructive part in the subsequent future of Namibia. Provided that the Namibian problem could be solved under the responsibility and control of the United Nations, the inclusion of the economic and scientific potentials of other countries by the government of independent Namibia would become an important factor for the country's own process of development.

The U.S.-based Lawyer's Committee for Civil Rights Under Law summarized the useful work done in that country over the past two decades. Its paper surveyed the current activities taking place in the United States on a number of levels to increase public awareness on the question of Namibia and to take concrete measures to assist the liberation process. The U.K.-based Namibia Support Committee focussed upon the Rio Tinto Zinc as bearing a particularly heavy burden of guilt for 
the plunder of Namibian uranium. In the course of developing a significant campaign of trade union action, the Committee has widened the scope of its research to include companies and industries involved in the purchase, transportation, processing and use of the uranium. It reminded that the Liverpool port workers halted shipments of uranium derived from Namibian ore.

Reginald Herbold Green suggested the following, which he described as "generally attainable targets": training, promoting and housing black Namibians on a more genuinely equal opportunity basis; negotiation with the legitimate trade unions in Namibia; dialogue with Christian bodies in Namibia leading to concrete social and economic action; withdrawal of support for repression; dialogue with the U.N. Council for Namibia and SWAPO on the possible roles of settlers and foreign enterprises in a genuinely independent Namibia. The speaker agreed that such an agenda would not liberate Namibia, nor even make a major contribution to doing so. He added that to expect more from the foreign enterprise/settler community would be pure romanticism.

Likewise, several reports dealt one and at the same time with $\mathrm{Na}$ mibian economy and the strategy to promote the independence of the country. Markus Braun, of the Christian Initiative Freedom for South Africa and Namibia, said that since the early 1970s, all world church bodies had taken decision to counter racism. In 1982, the World Alliance of Reformed Churches and in 1983 the Lutheran World Federation respectively, suspended the membership of the white churches in South Africa and Namibia because of their lack of commitment against the oppressive apartheid régime. In 1984, the synod of the Evangelical Church in Germany decided to review the contracts with the white partner churches in Namibia and South Africa. Several ecumenical and solidarity groups demanded the suspension of relating against military collaboration between the Federal Republic of Germany and South Africa.

Several other papers or statements made many interesting points. For instance, Ambassador S.A. Slipchenko, from the Soviet African-Asian Solidarity Committee, stated, inter alia, that for South Africa and its partners, Namibia is a major link in the system of control over the waters of the Atlantic and Indian Oceans and that therefore, Walvis Bay (the only deep water port in the country) was not only of economic, but also of strategic value. The representative of the Anti-Apartheid Movement in France explained how that organization, since its foundation in 1975, lent its active support to the struggle for the immediate independence of Namibia led by SWAPO. However, despite repeated appeals for a change in government policy, the positions of the French public aut- 
horities remained unchanged. Limited sanctions against South Africa came in the Summer of 1985. As regards Namibia, the only initiatives. taken by the French Government have been the suspension of participation in the work of the contact group and the authorization of the opening of SWAPO office in Paris. Nothing has been done to end French interests. in Namibia; many French companies are still involved there. The paper of the Swedish National Youth Council contained several suggestions in terms of youth exchange programs, projects and consultation mechanisms as contributions to the overall framework for joint action regarding cultural cooperation.

Masaharu Ie from Japan dwelled on the immediate imposition of comprehensive mandatory sanctions, under Chapter VII of the U.N. Charter as one of the most urgent steps for the attainment of Namibia's independence. He reminded that the Security Council, by its Resolution: 418 (1977), had already decided the prohibition of the export of weapons and other military goods to South Africa. However, it had failed to impose comprehensive mandatory sanctions. More pressure from world public opinion was needed to realize more effective enforcement measures. The same conclusion was expressed in the paper of Alaba Ogunsanwe from Nigeria, who urged the international community to renew with greater vigour its multi-dimensional approach to the securing. of independence for the people of Namibia $(8,9,11,12)$.

The participants of the Istanbul Seminar adopted a Declaration and a Call for Action. In summary, the Seminar supported the resolutions of the U.N. and called for their full implementation. It rejected attempts by South Africa to impose an internal settlement in Namibia outside the framework of the U.N. plan, embodied in the Security Council Resolution 435 (1978). It condemned the use of Namibian territory as a springboard for South African acts of aggression against front-line and other states, particularly Angola. It rejected attempts to establish a linkage between the independence of Namibia and extraneous issues. It emphasized that all such attempts were designed to delay further the independence of Namibia. The Seminar noted with concern that, since the most recent meeting of the Security Council in October 1987, there had been no decisive move towards the settlement of the Namibian question. However, the U.N. Secretary General, notably during his last visit to southern Africa, has continued to pursue his diplomatic efforts to secure the independence of Namibia. The Seminar commended the Secretary General for his tireless and skillful efforts to ensure the implementation of Resolution 435 (1978). It also requested him to pursue vigorously his: 
diplomatic initiatives with members of the Security Council. The Seminar also urged the three Western permanent members of the S.C. and the Federal Republic of Germany (which is currently a S.C. member) to take into account their particular responsibility, as initiators of the U.N. plan for the independence of Namibia. In view of South Africa's refusal to terminate its illegal occupation, the Seminar called upon the S.C. to adopt comprehensive and mandatory sanctions against the Pretoria régime under Chapter VII of the U.N. Charter. It expressed its support for the decision of the General Assembly to consider at its forty-third session necessary action in accordance with the Charter of the U.N., in the event of the inability of the S.C. to adopt concrete measures for the implementation of its Resolution 435 (1978) by September 29, 1988 at the latest.

The Seminar urged all states which maintain diplomatic and consular relations with South Africa, and particularly those having links to the so-called interim administration in Namibia, to sever all ties immediately. It called for increased pressure on states that collaborate with the South African régime. It also called for the intensification of peoples' and workers' sanctions and local government action in the form of boycotts and divestment actions directed against companies that maintain commercial links with South Africa and Namibia such as Shell, Rio Tinto Zinc, Standard Chartered Bank, Hudson Bay and Annings, Dresdner Bank, Thorer and Hollander, Foramer and the Newmont Mining Corporation.

The Seminar urged the U.N., governments, NGOs and parliamentarians to take further steps to enforce Decree No. 1 for the Protection of the Natural Resources of Namibia, including (a) pressure on governments which have not recognized the legal validity of the Decree to do so; (b) wider publicity against Urenco in the Netherlands; (c) additional research into violations of the Decree; (d) international coordination to support actions taken against violations of Decree No. 1, such as the Liverpool port workers' refusal to handle shipments of Namibian uranium; and (e) direct action against companies involved in illegal prospecting. It also urged to initiate assessment of the damages and taxes liable to be paid by those companies violating the Decree and to publish the names of the companies in arrears.

The Seminar called upon all states and international and non-governmental organizations to protest against the continuing oppression, detentions and illegal trials in Namibia; to extend material support to SWAPO and Namibian refugees; to provide scholarship for Namibian students; and to extend support to the National Union of Namibian 
Workers and its associated unions, to the National Namibian Students Organization and to the Council of Churches in Namibia.

The Seminar underlined the need for the media to present the question of Namibia as an issue in itself, and not only as a particular aspect of apartheid. It appealed to the media to present the question as one of decolonization and not in an East-West context. The media were also encouraged to assist in the training of Namibian journalists and to support the work of the Namibia Press Agency and the SWAPO Department of Information and Publicity. (12).

References in the Text :

1 Cronje, Gillian and Suzanne, The Workers of Namibia, London, International Defence and Aid Fund for Southern Africa, 1879.

2 Dreahsler, Hors, Le Sud-Ouest africain sous.Ia demination colonial allemande. Berlin, Akademie-Verlag, 1888.

3 König, Barbara, Namibia : the Ravages of War, London, International Defence and Aid Fund for Southern Africa, 1983.

4 Moleah, Alfred T., Namibia: the Struggle for Liberation, Wilmington, Delaware, Disa Press, 1983.

5 Moorsom, Richard, Walvis Bay : Namibia's Port, London, International Defence and Aid Fund for Southern Africa, 1884.

6 - Fishing : Exploiting the Sea, London, Catholic Instituto for In. ternational Relations, 1984.

7 SWAPO, To Be Born a Nation : the Liberation Struggle for Namibia, London, Zed Press, 1981.

8 United Nations, A Principle in Torment, New York, 1971.

9 U.N., A Trust Betrayed : Namibia, New York, 1974.

10 U.N., Plunder of Namibian Uranium, New York, 1882.

11 United Nations Institute for Namibia, Namibia: a Direct United Nations Reponsibility, Lusaka, 1987.

$12 \longrightarrow$, Namibia : Perspectives for National Reconstruction and Development, Lusaka, 1886. 